\title{
Hyaloriaceae Lindau, A New Family Record for Turkish Mycobiota
}

\author{
Yasin UZUN ${ }^{1}$, Abdullah KAYA*1, \\ Semiha YAKAR ${ }^{1}$, İbrahim Halil KARACAN ${ }^{2}$ \\ ${ }^{1}$ Karamanoğlu Mehmetbey University, Science Faculty, \\ Department of Biology, 70100 Karaman, Turkey \\ 2 Ömer Özmimar Religious Anatolian High School, \\ 7220, Gaziantep, Turkey
}

\begin{abstract}
A heterobasidioid fungi family Hyaloriaceae Lindau was recorded for the first time from Turkey based on the collection and determination of Myxarium nucleatum from Gaziantep province. Short description of the taxon are provided together with the photographs related to its macro and micromorphology.
\end{abstract}

Key Words: Macrofungi, new family record, Gaziantep, Turkey

\section{Hyaloriaceae Lindau, Türkiye Mikobiyotası İçin Yeni Bir Familya Kaydı}

Öz: Heterobasidioid bir mantar familyası olan Hyaloriaceae Lindau, Myxarium nucleatum'un Gaziantep'ten toplanıp teşhis edilmesiyle Türkiye'den ilk kez kaydedilmiştir. Taksona ait kısa betimleme, taksonun makro ve mikromorfolojisine ait fotoğrafları ile birlikte verilmiştir.

Anahtar Kelimeler: Makromantar, yeni familya kaydı, Gaziantep, Türkiye

\section{Introduction}

Hyaloriaceae Lindau is a basidiomycetous macrofungi family within the order Tremellales and characterized mainly by gelatinous basidiocarps and myxarioid basidia. The family was established by German mycologist Lindau in 1897 (Kirk et al., 2008). Members of the family generally grow on dead wood and plant remains and have a cosmopolitan distribution (Weiss and Oberwinkler, 2001). Currently three genera, Myxarium Wallr., Helicomyxa R. Kirschner \&
Chee J. Chen (Kirschner and Chen, 2004) and Hyaloria Möller are included in the family (Donk, 1966; Martin, 1945).

According to the current checklists (Sesli and Denchev, 2008; Solak et al., 2015) on Turkish macromycota no member of the family Hyaloriaceae have so far been recorded from Turkey.

The study aims to make contribution to the mycobiota of Turkey.

${ }^{*}$ Corresponding author:kayaabd@hotmail.com (Hyaloriaceae was presented as summary at $1^{\text {st }}$ National Plant Biology Congress in Bolu) 


\section{Materials and Methods}

Myxarium samples were collected from İslahiye district in 2014 during routine field trips carried out to determine the macrofungal diversity of Gaziantep province. The samples were photographed in their natural habitat, collected with care and transferred to the lab within paper bags. Micromorphologic structure were investigated and photographed under Nikon Eclipse Ci trinocular light microscope. Identification were performed with the help of Desjardin et al. (2015), Hauerslev (1993), Kisimova-Horowitz et al. (2000) and Martin (1944, 1945, 1952). The samples are kept at Karamanoğlu Mehmetbey University, Kamil Özdağ Science Faculty, Department of Biology.

\section{Results}

\section{Basidiomycota R.T. Moore}

Tremellales Fr.

Hyaloriaceae Lindau

Myxarium Wallr.

Myxarium nucleatum Wallr., FI. crypt. Germ. (Norimbergae) 2: 260 (1833)

Syn: [Exidia alboglobosa Lloyd, Exidia beardsleei Lloyd, Exidia gemmata (Lév.) Bourdot \& Maire, Exidia gemmata (Lév.) Bourdot \& Maire f. gemmata, Exidia nucleata (Schwein.) Burt, Exidia tremelloides L.S. Olive, Myxarium atratum (Peck) Ginns \& M.N.L. Lefebvre, Myxarium nucleatum f. ampulligerum Hauerslev, Myxarium nucleatum Wallr. f. nucleatum, Myxarium nucleatum Wallr. var. nucleatum, Myxarium tremelloides (L.S. Olive) Wojewoda, Naematelia atrata Peck, Naematelia gemmata (Lév.) Fr., Naematelia nucleata (Schwein.) Fr., Tremella gemmata Lév., Tremella nucleata Schwein.]

Macroscopic and microscopic features: Basidiocarp 2 to $10 \mathrm{~mm}$ in diameter, gelatinous, sessile, subglobose when young. Many of them often coalesce and form a convoluted to cerebriform compound fruit body or fuse into sheet-like masses up to 50-60 mm in diameter. Fruit bodies are hyaline to whitish when young (Figure 1a), vinaceous-brown to olive-brown when mature. Hymenium smooth. Odor not distinctive. Basidia 11-16 x 9-10.5 $\mu \mathrm{m}$, ellipsoid, longitudinally septate (Figure 1b,c). Spores 8.5-14 x 3.5-5 $\mu \mathrm{m}$, sausage-shaped, smooth, thin walled and with granular contex (Figure 1d).

Ecology: Myxarium nucleatum grows on decaying logs of various decidious woods especially of beech.

Specimen examined: Gaziantep -İslahiye, Tandır village, Huzurlu high plateau, mixed forest, on dead branches of beech, $36^{\circ} 58^{\prime} \mathrm{N}-36^{\circ} 30^{\prime} \mathrm{E}, 1430 \mathrm{~m}, 19.10 .2014$, K.10087.

\section{Discussion}

Due to its hyaline to whitish jelly structure, Myxarium nucleatum may be confused with Tremella encephala Pers when young. But their colour differs at maturity. Myxarium nucleatum becomes vinaceous to olive-brown in age while Tremella encephala becomes pale yellowishtan. Additionally Tremella encephala usually grows in association with Stereum sanguinolentum (Alb. \& Schwein.) Fr. on conifers while Myxarium nucleatum occurs only on hard woods (Breitenbach and Kränzlin, 1986).

Almost 26 jelly basidiomycetous taxa have so far been recorded within the families Auriculariaceae Fr., Dacrymycetaceae J. Schröt, and Tremellaceae Fr., and the genera Auricularia Bull., Calocera (Fr.) Fr., Dacrymyces Nees, Exidia Fr., Guepiniopsis Pat. and Tremella Pers. With this study the determined jelly basidiomycetous family number in Turkey increased to five, genera number increased to eight and the species number increased to 27 .

\section{Acknowledgements}

The authors would like to thank TÜBITAK for supporting the Project (212T112) financially. 


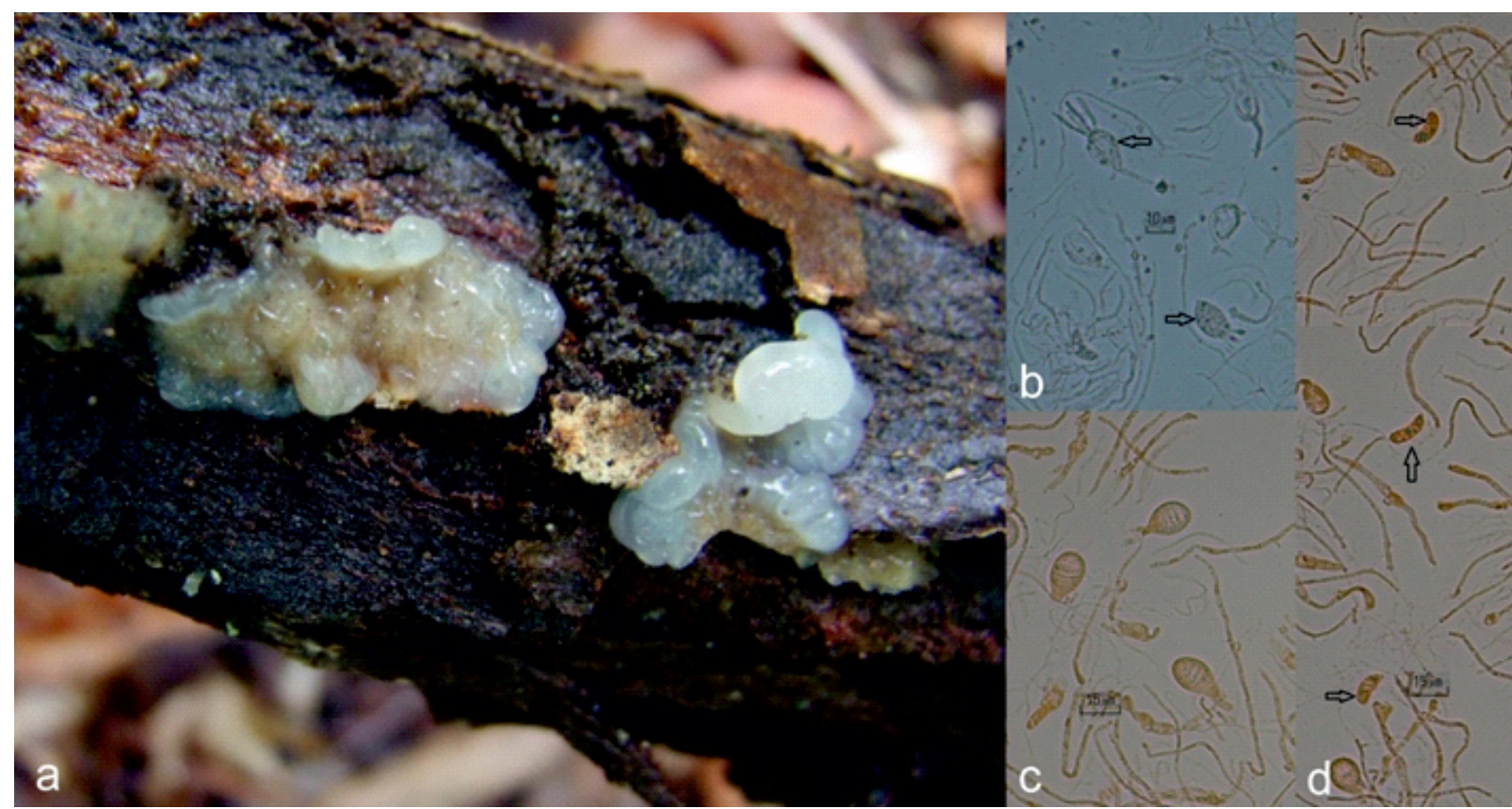

Figure 1. Myxarium nucleatum: a. basidiocarps, b,c. basidia, d. basidiospores

\section{References}

Breitenbach J., Kränzlin F. Fungi of Switzerland. Volume 2: Non-Gilled Fungi. Luzern, Switzerland: Verlag Mykologia. 412p. (1986).

Desjardin D.E., Wood M.G. Stevens F.A. California Mushrooms: The Comprehensive Identification Guide. Timber Press: Portland, Oregon. 560 p. (2015).

Donk M.A. Check list of European hymenomycetous Heterobasidiae. Persoonia 4: 145-335 (1966).

Hauerslev K. The genus Myxarium (Tremellales) in Denmark. Mycotaxon, 49: 235-256. (1993).

Kirk PF, Cannon PF, Minter DW, Stalpers JA (2008). Dictionary of the Fungi, $10^{\text {th }}$ ed. Wallingford, UK: CAB International.

Kirschner R., Chen J. C. Helicomyxa everhartioides, a new helicosporous sporodochial hyphomycete from Taiwan with relationships to the Hyaloriaceae (Auriculariales, Basidiomycota). Studies in Mycology. 50(2): 337-342. (2004).

Kisimova-Horovitz L., Oberwinkler F., Gomez L.D.P. Basidiomicetos resupinados de Costa Rica. Myxariaceae s. Jülich, Sebacinaceae Wells \& Oberw., Tremellodendropsidaceae Jü!ich. Rev. Biol. Trop., 48(2/3): 519-538. (2000).

Martin G.W. The Tremellales of the North Central United States and Adjacent Canada. University of lowa: lowa City, IA. 88 p. (1944).

Martin G.W. The classification of the Tremellales. Mycologia 37(5): 527-542 (1945).

Martin G.W. Revision of the North Central Tremellales. State University of lowa. 122 p. (1952). 


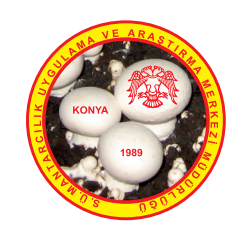

Sesli, E. \& Denchev, C.M. 2008. Checklists of the myxomycetes, larger ascomycetes, and larger basidiomycetes in Turkey. 6th edn. Mycotaxon Checklists Online (http://www.mycotaxon.com/resources/checklists/sesli-v106checklist.pdf): 1-136.

Solak M.H., Işıloğlu M., Kalmış E., Allı H. Macrofungi of Turkey, Checklist, Volume- II. Üniversiteliler Ofset, Bornova, İzmir( 2015).

Weiss M, Oberwinkler F. Phylogenetic relationships in Auriculariales and related groups - hypotheses derived from nuclear ribosomal DNA sequences. Mycological Research 105: 403-415(2001). 